\title{
Colonialismo, racismo y clasismo en la imagen audiovisual del indígena en México: una propuesta de análisis.
}

\section{Colonialism, Racism and classism in the indigenous audiovisual image in Mexico: an analysis proposal}

\author{
Israel León $O^{\prime}$ Farrill $^{a}$
}

\begin{abstract}
:
The indigenous image in the audiovisual productions (cinema and television) in most of the twentieth century, was based on the ideas of cultural miscegenation promoted from the State and executed by writers, directors and producers who, convinced of their role in that same nationalist mission, collaborated decisively so that these models penetrated the social imaginary of our country and the region. Through this essay, I expose this situation and then, offer a proposal for analysis based on the dialogism of Mijaíl Bakhtin and the semiotics of culture proposed by Yuri Lotman.
\end{abstract}

Keywords:

Cinema, television, indigenism, dialogism, cultural semiotics

\section{Resumen:}

La imagen del indígena en las producciones audiovisuales (cine y televisión) en casi todo el siglo XX, estuvo supeditada a las ideas de mestizaje cultural propiciadas desde el Estado y ejecutadas por escritores, directores y productores que, convencidos de su papel en esa misma misión nacionalista, colaboraron de forma decisiva para que estos modelos penetraran en el imaginario social de nuestro país y la región. Mediante este ensayo, expongo esta situación para más adelante ofrecer una propuesta de análisis sustentada en el dialogismo de Mijaíl Bajtín y la semiótica de la cultura propuesta por Yuri Lotman.

\section{Palabras Clave:}

Cine, television, indigenismo, dialogismo, semiótica de la cultura

\section{Introducción}

La década que corre ha estado pletórica de reivindicaciones sociales y su expresión ha sido diversa: manifestación masiva en las calles, con o sin violencia; en redes sociales, principalmente en Facebook, Twitter y en el correo electrónico, vía la plataforma change.org. Uno podría decir que, en los últimos años, hemos experimentado una vorágine de emociones. Los temas han sido muchos, pero diría que los más importantes han gravitado en torno al reconocimiento de los derechos de las denominadas "minorías" (en especial los de las mujeres y de las personas LGBTTT+) y en la exigencia del respeto a los derechos humanos y aquí destaca, como un pendiente enorme, las desapariciones forzadas (los 43, el caso más emblemático), el asesinato sistemático de defensores medioambientales 0 comunitarios, de periodistas y las muertes relacionadas con la lucha contra el crimen organizado.
Mención especial requiere el tema de las mujeres, pues no sólo la exigencia va dirigida a la consecución de un equilibrio entre los géneros, sino que va directamente a la destrucción del patriarcado en sus numerosas expresiones. Por tanto, demandan su derecho a decidir sobre su cuerpo; el fin de la violencia de género, con especial énfasis en los feminicidios; la eliminación del acoso sexual en todos los ámbitos y, por supuesto, su reconocimiento laboral, familiar, social y un largo etcétera.

Por supuesto, también está el asunto de la reivindicación de los llamados "pueblos originarios" que ha dependido de aspectos como la moda, las fechas emblemáticas en el calendario como el 12 de octubre o la fiesta de muertos, la celebración de la Independencia Nacional e inclusive la celebración de la Revolución Mexicana y, a través de las noticias que fluyen a cuenta gotas, sobre hallazgos prehispánicos, resistencia de una $u$ otra comunidad al avance de proyectos productivos neoliberales (tanto de la 
iniciativa privada como gubernamentales) o el que una actriz o película centradas en comunidades indígenas reciban reconocimiento nacional e internacional.

En este sentido, la realización de imágenes audiovisuales y su posterior exhibición en cine o televisión, principalmente en las producciones de ficción, exhiben tendencias colonialistas, racistas y clasistas desde los inicios del cine hasta nuestros días. Lo anterior, en mayor o menor medida, ha respondido, primero, a las políticas nacionalistas promovidas por los gobiernos postrevolucionarios y segundo, por el aprovechamiento de estereotipos desarrollados por los medios de comunicación masiva, elemento fundamental para la venta de sus producciones. Todo ello ha contribuido a la construcción y consolidación de una imagen estereotipada del indio, centrada en su marginalidad, y una supuesta "inferioridad" intelectual, económica y social; a la par, su supuesta "tozudez" llevada a lo irracional lo que los hace no sólo no sumarse a la modernidad, sino ser un "obstáculo para el progreso" del país completo. Por tanto, el tema central de este ensayo es la imagen que se ha construido sobre lo indígena en los medios audiovisuales, principalmente el cine y la televisión y sus consecuencias en la concepción que de los pueblos indígenas se ha construido nuestra sociedad.

\section{Indio- indígena}

Para iniciar el presente análisis es pertinente abordar los conceptos "indio" e "indígena" que a la fecha ha venido utilizándose como sinónimos. Guillermo Bonfil Batalla afirma que "El indio nace cuando Colón toma posesión de la isla Hispaniola a nombre de los Reyes Católicos. (...) No había "indios" ni concepto alguno que calificara de manera uniforme a toda la población del Continente" (1972: 110). Como vemos, la categoría indio o indígena, sea cual sea su origen, es consecuencia del encuentro con el "otro", pero no en el sentido expresado por José Alejos basado en Bajtín, "como la integración de dos logos" (2006: 4), es decir, de dos formas de pensar y concebir el mundo, sino en una forma enteramente colonial, de subordinación. El "indio" o el "indígena", son conceptos que derivan de una acción "colonizadora y civilizatoria" que se crea en el siglo XVI, pero que adquirirá su sentido más lamentable en el siglo XIX como producto de los esfuerzos liberales por construir "nación" y se verá reforzado por las políticas indigenistas posteriores a la Revolución Mexicana. Bonfil continúa:

Es, evidentemente, una categoría supraétnica que abarca indiscriminadamente a una serie de contingentes de diversa filiación histórica cuya única referencia común es la de estar destinados a ocupar, dentro del orden colonial, la posición subordinada que corresponde al colonizado. El problema consistiría en definir si la persistencia de la categoría social indio corresponde efectivamente a la persistencia de una situación colonial, o si debe entenderse como un remanente que ya no está sustentado por el orden social —colonial- que le dio origen (1974: 119).

Para Bonfil, lo ideal sería centrar la mirada en la identidad étnica desarrollada por los propios pueblos. Con ello, piensa que el respeto estaría garantizado. Sin embargo, como bien apunta Luis Vázquez (2010), una construcción identitaria artificial propuesta por el Estado (como sucedió con la "purepechización" de las etnias en Michoacán) tampoco ha resultado la solución del todo. Acaso, como lo pude constatar con las comunidades itzaes, mestizas y criollas en el Petén Guatemalteco en una investigación, cuyos resultados publiqué recientemente (León, 2020), la identidad maya itzá ha sido adoptada de forma bastante tímida por los propios itzaes (producto de la violencia institucional ejercida contra los pueblos mayas en diferentes momentos del siglo XX) y de forma abierta por parte de mestizos, criollos y recién llegados a la region. Es decir, en ocasiones la identidad étnica no es asumida propiamente por la etnia en cuestión, sino por las sociedades mestizas. En todo caso, es necesario referirnos a ellos con el nombre que ellos mismos se han dado, como "wixárika" en lugar de huichol o "tojolwinik'otik" en lugar de tojolabales

Considero que la condición colonial pervive hasta nuestros días y que ambas categorías, indio e indígena, responden todavía a la diferenciación. Es, como lo ha denunciado Dussel, un encubrimiento del otro bajo estas categorías: 'El 'cubierto' ha sido 'des- cubierto': egocogito- cogitatum, europeizado, pero inmediatamente 'encubierto' como Otro" (1994: 64). Por supuesto, ese otro se encuentra indefectiblemente subordinado a la categoría empleada para designarlo con todos los defectos o virtudes que se le pueda transferir desde la omnipotencia europea, sea primero la conquistadora/ colonizadora; después la independiente/ mexicana/ postrevoucionaria nacionalista; o aquella propuesta por el disciplinamiento académico (de raigambre positivista) que canalizó su estudio en la Historia, la Antropología, la Sociología, la Economía.

La visión del indio o del indígena queda sujeta a una dualidad que agudamente señala Luis Villoro:

Por fin, se revela el ser indígena, como una realidad de doble fondo. No es objeto puro, facticidad simple (salvo en el caso de Orozco), pero tampoco es trascendencia reconocida. Es objeto fáctico a la vez que capacidad de trascendencia nunca realizada. De ahí que aparezca siempre — cuando lo juzgamos y determinamos- como disfrazado y oculto. Nos percatamos de que nunca lo captamos en su propio ser, de que siempre se nos escapa en algo. De ahí también que su mundo se revele - tan a menudoen una doble dimensión: en tanto determinado desde 
fuera y en tanto capaz de significados propios. (1996: 295).

En el presente ensayo, daré cuenta de la forma en que el cine y la televisión han construido una imagen del "indio" o del "indígena" no sólo como sinónimos, sino como una caricatura sintética con el afán de producir una identidad nacional, primero, para luego constituirlo en un personaje "tipo" fácil de identificar con el atraso y la pobreza que se hermanan con la picardía y la astucia. Asumo la postura de Bonfil de "indio" e "indígena" como categorías emergidas de la colinización de estos territorios y con Dussel el permanente "ocultamiento" detrás de estos conceptos que bien han asumido los medios de comunicación. Como afirma Federico Navarrete: "en el imaginario racista de dichas élites mexicanas los indígenas del sur y del país hablan todos como Tizoc, es decir, como Pedro Infante disfrazado de indio sumiso para el cine mexicano, y los del norte hablan como indios piel roja" (2016: 14).

\section{Nacionalismo, colonialismo, indigenismo y racismo}

Federico Navarrete, en su libro "México Racista, una denuncia" (2016) afirma que en México existen muchas formas de discriminación y todas van dirigidas a acentuar la diferencia, sea por género, preferencia sexual, edad, grado de estudios y nivel socioeconómico. "De estas múltiples formas de exclusión, una de las más difundidas y más dañinas es el racismo, que discrimina a las personas por su color de piel, la forma de su cabello y sus rasgos faciales, pero también por su cultura, su forma de vestir y de pensar, que son considerados índices de su pertenencia a una 'raza' supuestamente inferior" (2016: 11). En efecto, quizá una de las formas de discriminación más normalizada es aquella que va dirigida a disminuir al otro a partir de su color de piel, su herencia étnica, apellido, origen (ciudad, población, estado) o vestimenta. Todo ello va relacionado con estereotipos que tienden sus raíces profundamente en el pasado colonial de nuestro país, pero que fueron fuertemente consolidados en nuestras etapas independiente (siglo XIX) y postrevolucionaria.

El Estado mexicano, surgido de la Revolución Mexicana, desarrolló a través de múltiples intelectuales entre los que destacarían Gamio y Vasconcelos, políticas educativas y culturales tendientes a la construcción de lo "nacional", muy en el sentido de los nacionalismos de la primera mitad del siglo XX: el encumbramiento de lo indígena, así en abstracto, como el origen de nuestra patria que, una vez conquistada, se ve complementada con la cultura europea en una suerte de mestizaje cultural, muy al estilo de lo que ha propuesto Gruzinski (1990/2006). Más allá de que tal mestizaje se realizó (cosa a discutir, indudablemente), la realidad de los pueblos indígenas ha sido muy distinta. Pese a que muchas de las reivindicaciones surgidas de la Revolución, para el pueblo en general, pudieran haber impactado a las comunidades indígenas, lo hicieron de manera circunstancial, pues lo importante fueron los rubros políticos en mayor medida, y el agro quizá en menor medida. Parte del discurso de los grupos zapatistas y villistas quedaría integrado en la Constitución de 1917; sin embargo, no será sino hasta muchos decenios después que se integrará a la carta magna el concepto de "nación pluricultural", con lo que al menos en el discurso se integra al mundo indígena en la dinámica nacional. En todo caso, las figuras populares de la lucha armada, habrán de quedar impresas en el discurso nacionalista asumido por el Estado, y serán transformados en próceres de la nación. A la vez, vemos que los conceptos campesino e indígena se imbrican en uno solo y ambos terminan eternamente relacionados con la pobreza.

Vasconcelos fue una de las figuras emblemáticas en los esfuerzos por definir lo nacional y el nacionalismo; sin embargo, vemos en los estudios realizados por Brading (2004 a y b), Stern (2000) y Gutiérrez (2001, 2015) el sentido real de la búsqueda vasconcelista: el encumbrar al mestizo, tanto racialmente como culturalmente, al lugar privilegiado que la historia le había negado. Vasconcelos es heredero de las ideas basadas en el darwinismo social de Molina Enríquez, así como de las ideas positivistas de Justo Sierra, vinculadas en cierta medida pese a la crítica, con el Ateneo de la Juventud. La suya, en opinión de Brading, es una postura romántica, pues ve en las tradiciones y en la cultura el fermento de la nacionalidad (2004b: 189); sin embargo, al igual que otros románticos anteriores terminó construyendo un híbrido entre la modernidad y un pasado prehispánico inexistente por perfecto. Algo similar habría de suceder con Gamio que, pese a realizar lo que pudiéramos señalar como los primeros trabajos de rescate arqueológico y estudios etnográficos en Teotihuacan, tendió a la subordinación del discurso indigenista al proyecto de nación surgido de la contienda civil de 1910. Podemos vislumbrar como lo han señalado Hale (2002), Stern (2000), Brading (2004 a y b) y Florescano $(2003,2005)$ una línea ideológica en torno al discurso indigenista, desde las postrimerías de la Reforma hasta bien entrado el siglo XX; una línea que ha sido acompañada directamente por el positivismo como política de estado pero que, matizada por la Revolución, tendió a ofrecer una respuesta quizá más incluyente en lo que respecta a las luchas populares, pero que en la realidad, poco o nulo impacto tuvo para con las comunidades indígenas. Ejemplo de ello fue el despojo del que fueron objeto dichas comunidades después de la aplicación de las leyes de reforma, concretamente en lo concerniente a la desamortización de los bienes eclesiales y los llamados terrenos baldíos, que 
comunmente pertenecían a las comunidades indígenas. Lo cierto es que desde el siglo XIX, la visión del indígena como un obstáculo para el avance socio económico de México ha quedado de manera permanente en la mente de gobernantes y gobernados.

Es interesante ver que el indigenismo como política seguida por los gobiernos surgidos de la Revolución está por entero dirigida a la asimilación de estos pueblos al tren de la modernidad, de manera vertical y sin diálogo. Podemos ver que los esfuerzos seguidos por las subsecuentes administraciones han sido en este sentido, y que con objetivos netamente nacionalistas, muchos intelectuales de las décadas de los treinta, cuarenta y bien entrada la de los cincuenta, habrán de sumarse a la construcción de lo nacional partiendo de los elementos indígenas que mejor pudieran adaptarse a las necesidades del grupo al que pertenecían y con la pretensión de ver en ellas un universalismo artificial. Federico Navarrete afirma que "la política indigenista permitiría culminar la construcción de las naciones indomestizas americanas como unidades orgánicas y raciales, libres de antagonismos culturales y resistencias a la aculturación" (2018: 32). En un análisis del texto de Aguirre Beltrán, "El Proceso de Aculturación" (1957), nos muestra que ahí se encontraba el foco ideológico que habría de acompañar a las políticas de integración desde el poder y que tenían una línea claramente evolucionista (2018: 31- 32) Como ejemplo de lo anterior, comparto una cita del libro de Aguirre Beltrán:

El indigenismo es la expresión cultural de un fenómeno biológico, el mestizaje, el cual resulta inteligible sólo como producto de la emergencia y elevación del mestizo en el plano histórico. La teoría social que norma la acción política de los países latinoamericanos respecto al indio es lo que recibe la designación de indigenismo, pero la base orgánica de tal ideología está representada, no ciertamente por el indio, sino por el mestizo. Indigenismo y mestizaje son procesos polares que se complementan, al punto de tornarse imposible su existencia separada. El indigenismo requiere, como condición sine qua non de su ser, el substratum humano que le suministra el mestizaje. Éste, a su vez, requiere, para dar contenido y significación a la vida, el sistema axiológico que el indigenismo sólo puede proporcionarle. La interdependencia entre la base orgánica y la expresión cultural deviene indispensable (1957: 126- 127).

Como se ve, el indigenismo lleva implícito el mestizaje, como una especie de objetivo ideal a largo plazo. Por supuesto, no habría integración de los pueblos al debate de lo nacional, sino su asimilación en esta entelequia que denominamos México mestizo.

Al igual que el indigenismo, el cine que denominaré para efectos de este ensayo "indigenista" prefigura una visión generalizada de lo indígena y tiende a la creación de estereotipos que poco se vinculan con la realidad de la tradición oral y escrita de estas comunidades. Fueron películas hechas por mexicanos para mexicanos, no necesariamente para indígenas. El indigenismo en literatura fue considerado como una de las vanguardias del siglo XX junto con el folclorismo, la novela colonial, la poesía negra y otras expresiones que serían consideradas también como localistas; el cine, partiría de una idea similar. Un rasgo en común de varias de estas películas, al igual que muchas novelas indigenistas, es que utilizaron como estrategia literaria elementos del folclore local, en una suerte de regionalismo. Ello trajo atención de los espectadores en diversas partes del orbe por considerar su expresión "exótica".

Independientemente de las posibles intenciones de los directores, vemos que funcionaron bien, tanto en México, como en otras partes del mundo, pues algunas de estas películas obtuvieron premios en Festivales Internacionales. Sin embargo, es mi opinion, después del análisis que, no obstante los posibles éxitos de directores y películas, la visión de lo indígena quedó relegada quizá a simples efectos del folclore y no impactó realmente a las comunidades que los autores decían retratar.

Figura 1. Pedro Armendaríz y María Elena Marqués en escena de la película "La Perla"

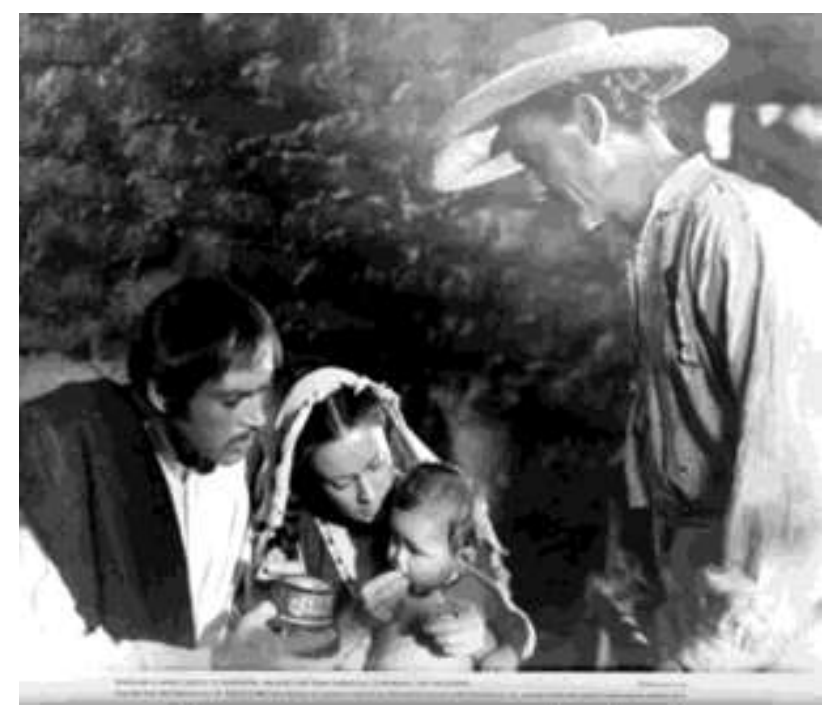

Fuente: (1945). Archivo Casasola.

\section{El cine y la televisión}

María del Rosario Vidal (2011), investigadora de la Universidad de Gudalajara, afirma que el poder se valió del cine como una vía de transmisión del modelo de Nación y sus posibilidades:

...durante dicha etapa el gobierno encabezado por un líder carismático como Lázaro Cárdenas marcó la pauta para el eventual empleo del cine como un medio de propaganda acorde con los intereses del 
Estado que, surgido de la Revolución Mexicana, debió impulsar una serie de transformaciones que terminarían por dar forma al sistema político que, a pesar de todo, logró prevalecer durante varias décadas, hecho que se tradujo en un clima de relativa calma, suficiente para permitir avances y logros en diversas áreas de la vida nacional (2011: 49).

Por tanto, la incursión de temas de lo "nacional" en el cine, especialmente en la denominada "Época de Oro" del cine nacional (1935 a 1956) contribuye no sólo a la política de construcción de identidad del régimen, sino, a la colonización del imaginario social mediante una relación de dominación donde el indio queda subordinado al "otro", representado por el blanco o el mestizo. "Así, las películas de la Época de Oro naturalizan en la pantalla aquello que debe ser entendido como la esencia de la 'mexicanidad' y, con esa naturalización, instalan en el imaginario social la ideología del multiculturalismo restringido" (Silva, 2011: 12).

Por tanto, la elaboración de guiones -muchas veces basados en novelas de corte indigenista y desarrollados por sus autores- y películas responderán a los intereses de esa representación de la mexicanidad. Se elabora un modelo de indígena desprovisto de identidad étnica o regional, salvo que estas sirvan para acentuar cierto dramatismo; se trata de la construcción de un estereotipo asimilable por el público en general que asistía a las salas de proyección (De la Peña, 2014: 108). Ejemplos de lo anterior son "Janitzio" (1935) de Carlos Navarro; "El Indio" (1939) de Armando Vargas de la Maza, basada en la novela del mismo nombre escrita por Gregorio López y Fuentes y cuya adaptación fue realizada por Celestino Gorostiza; "Maclovia" (1948) de Emilio "El Indio" Fernández, una readaptación de "Janitzio"; "María Candelaria" (1944) y "La Perla" (1947), ambas también de Fernández. De igual manera, "La Rebelión de los Colgados" (1954) de Alfredo B. Crevenna, película basada en la novela homónima de Bruno Traven quien hizo también el guion, pero con seudónimo (Hal Croves); "Chilam Balam" (1955), de Íñigo de Martino, supuestamente basada en las profecías mayas de Chilam Balam; "Tizoc" (1957), de Ismael Rodríguez, con un Pedro Infante caracterizado como indígena.
Figura 2. Pedro Infante y María Félix con directores en la filmación de la película "Tizoc" (1956).

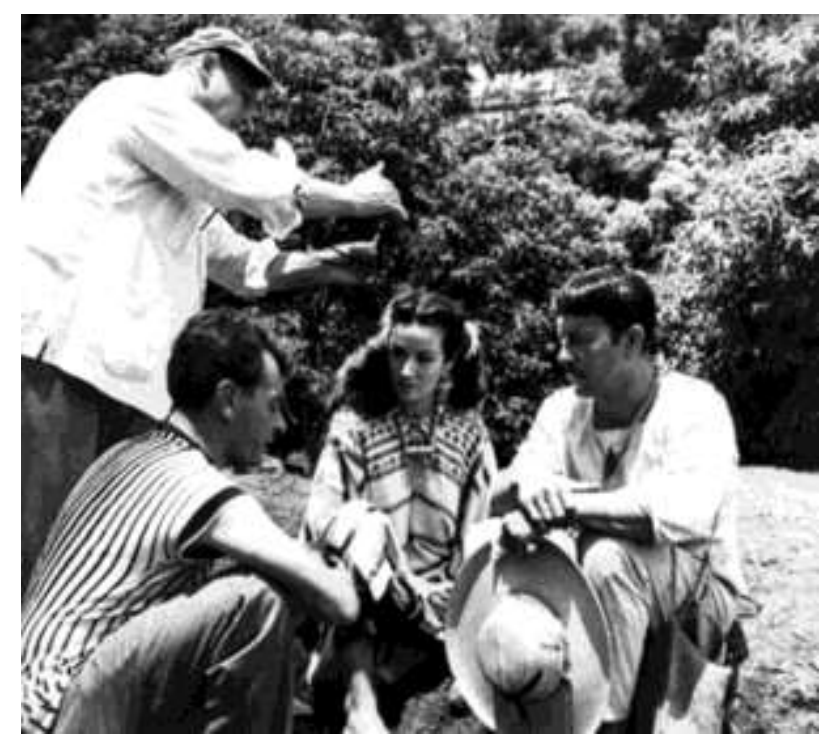

Fuente: Archivo Casasola.

Los indios rara vez son interpretados por hombres y mujeres de las comunidades indígenas aludidas en la historia. Usualmente son representados por actores y actrices que nada tienen de indígena y el único recurso al que acuden los realizadores es a "pintarles 0 embetunarles" la piel para que se vean más morenos. Casos emblemáticos son los de Pedro Armendáriz que interpreta numerosos papeles de indígenas en la pantalla, Dolores del Río en "María Candelaria”, Ariadne Welter en "La Rebelión de los Colgados" o María Felix en "Maclovia", por citar unos ejemplos.

Mención especial lleva "La India María" interpretada por María Elena Velasco Fragossi desde finales de los años sesenta del siglo pasado. Interpretó al personaje en numerosas películas consolidándolo como una de las referencias obligadas cuando nos referimos a la presencia de la mujer indígena en el cine. Para Castro

Primero como actriz y luego combinando este oficio con su papel de realizadora, María Elena Velasco (la India María) puso en circulación imágenes que se afirmaron como elementos de identidad para decenas de miles de espectadores mexicanos y se convirtieron en uno de los productos más relevantes en el marco de la cultura popular mexicana entre los años 1970 y 1980 (2011: s/p).

Su carrera fue importante en muchos sentidos, como se ve en la cita anterior; sin embargo, su personaje es quizá uno de los que más arraigó el estereotipo del indio en la mente de los mexicanos.

Por su parte, la Televisión representó un canal más de continuidad a lo producido por el cine, aunque en su caso, 
añadió fuerza al estereotipo de lo indígena. Como un poderoso aliado del poder, la televisión reforzó esquemas e identidades a través de la reproducción de historias repetitivas donde los estereotipos de género, raza y clase se consolidaron. Podemos decir que las empresas televisivas, especialmente Televisa, han contribuido de manera importante a una especie de adormecimiento social y han fomentado el racismo y el clasismo.

En 1949 cuando se elaboró el reglamento para el funcionamiento de la televisión en México, se estipuló que el Gobierno haría uso de la televisión con fines sociales, culturales, además de comerciales. Pero fue hasta el siguiente año que El Diario Oficial de la Federación publicó el decreto que fijó las normas a que se sujetarían las estaciones de Televisión (Sánchez, 1991). (...) El nacimiento de la televisión como un decreto presidencial marcó la complicidad entre el Estado y las élites empresariales. Se interpreta como una alianza camaleónica entre el poder representado por los regímenes priistas y personajes de la cúpula empresarial (Pérez y Leal, 2017: 174).

Además, al ser un medio con mayor penetración que el cine, trajo consigo un importante refuerzo no sólo de la imagen, sino de las actitudes hacia los pueblos indígenas. Curiosamente, la caricaturización del indígena ha tenido una vía esencial en la comedia, pues ha resultado a comediantes y productores un "tipo genial" de comicidad. En consecuencia, el medio televisivo se dedicó a explotar con bastante éxito los estereotipos de lo indígena: la supuesta ignorancia, el estilo de hablar sumiso y la incorrección del lenguaje llevados ambos a la caricatura lo mismo que la eterna vestimenta "indígena" basada en la grosera síntesis de muchos de los trajes regionales del país; en el mejor de los casos, se le diseñó como un personaje taimado, ágil y que siempre se salía con la suya. Todas estas características las cumplía la India María, acaso punto de partida de muchos otros personajes televisivos. Ejemplos sobran, pero vale la pena mencionar a Francisco Fuentes con su personaje "Madaleno" (que provenía de las carpas y el cine donde hacía la dupla con Manuel Tamez "Maclovio"), que participó por años en el Club del Hogar (1951-1985); "Chano y Chon", interpretados por Eduardo Manzano y Enrique Cuenca, "Los Polivoces"; "Maclovio Jackson" interpretado por Luis de Alba en múltiples programas de televisión. En la actualidad destaco los personajes "El Indio Brayan" ejecutado por Hugo Alcántara y la "India Yuriria" interpretada por Yuridia Ruiz Castro, ambos con presencia importante en la plataforma YouTube.

Por su parte, en las producciones comúnmente conocidas como telenovelas, la figura del indio está desarrollada con frecuencia para mostrar un antes y un después en la idea moderna de desarrollo; además, suelen ser personajes femeninos. Por tanto, se presenta a la "indita" que llega a la Capital y después de mucho sufrimiento, generalmente a manos de personajes de clase acomodada, logra sobreponerse, sustituir su condición indígena, "sumisa e ignorante" al estudiar y formarse como persona "civilizada" y colocarse en el lugar que le corresponde: arriba de los demás. Ejemplos de esta premisa son "Simplemente María" (1990), producida por Valentín Pimstein y protagonizada por Victoria Ruffo donde interpreta a una mujer de campo que viste ropa y usa un peinado "indígena", aunque realmente no sabemos si lo es; "María Isabel" (1997) de la productora Carla Estrada y protagonizada por Adela Noriega que interpreta a una indígena huichol, con toda la sorpresa que tal afirmación nos pueda provocar; "Un refugio para el amor" (2012) producida por Ignacio Sada e interpretada por Zuria Vega, que también, contra todo pronóstico, interpreta a una indígena. Lo interesante del asunto es que, al igual que en el cine, la presencia indígena es nula en estas producciones. De hecho, se busca en la medida de lo posible, que las protagonistas parezcan lo menos indígena posible, aunque el papel así lo determine.

Monitorizando los principales canales televisivos, así como otros medios, se observa, según Herrero (2013) la ausencia de mujeres morenas o indígenas (al igual que en el caso de los hombres). El estereotipo de mujer que representa la televisión y los demás medios es el de la mujer blanca, si es morena aparecerá con algún rasgo occidental o reproducirá el estereotipo europeo y anglosajón de lo latino. ¿Dónde están las otras mujeres en un país donde el porcentaje de mujeres morenas es superior al de mujeres blancas? Lo que es visible en todo esto es que existe un proceso colonizador en la imagen o en las representaciones de la mujer mexicana que afecta a todas las producciones culturales. Este fenómeno está arraigado en todos los niveles de las esferas públicas, mediática y política, es tan cotidiano que pasa desapercibido (Pérez y Leal, 2017: 179).

En efecto, el color de piel y los rasgos indígenas quedan fuera por completo de la representación. No obstante, con independencia de quien interprete el personaje, pareciera que el estereotipo de lo indígena penetra al final en la mente de los espectadores.

Para Lepe-Carrión, el asunto queda en estos términos: La idea de civilizar la barbarie, de integrar a las comunidades incivilizadas al proyecto de la Modernidad, es un concepto que atraviesa casi toda la historia de América, y que desde la Colonia y la República (y hasta la actualidad) se ha venido instalando como una columna vertebral en las múltiples estrategias de poder que pretenden clasificar y definir los cánones de lo 'racional', de lo 'cultural' o de lo 'identitario'. Idea etnocéntrica - sin duda-, propia de comunidades 'aquejadas de un localismo estrecho, ignorante y a menudo feroz' (Fernández Retamar, 1989: 292), y que Europa 
acuña en su seno del pensamiento invasivo y conquistador (ego conquiro), sólo a partir de su autoconformación moderna como 'centro' de la historia universal, esto es, sólo a finales del siglo XV; hasta entonces, Europa sólo era una periferia del mundo árabe (Dussel, 2000)" (Lepe- Carrión, 2012: 64).

En las telenovelas, las protagonistas que triunfan son las que vencen su "barbarie" y asumen la civilidad urbana, que es donde se encuentra el desarrollo y el progreso. Quijano afirma que la "raza se convirtió en el primer criterio fundamental para la distribución de la población mundial en los rangos, lugares y roles en la estructura de poder de la nueva sociedad. En otros términos, en el modo básico de clasificación social universal de la población mundial” (2014: 780). Por supuesto, este concepto del racismo, es una de las expresiones más exitosas del pensamiento colonial, pues permite que los sujetos se encuentren clasificados en una pugna constante entre buenos y malos; desarrollados y subdersarrollados; blancos y todos los demás. Sumada a la idea de la raza, se integra la idea del capitalismo como doctrina económica indefectiblemente vinculada a occidente y al pensamiento colonial. Por tanto, "Así, ambos elementos, raza y división del trabajo, quedaron estructuralmente asociados y reforzándose mutuamente, a pesar de que ninguno de los dos era necesariamente dependiente el uno del otro para existir o para cambiar" (2014: 781). Y, sin embargo, en el imaginario nacional, tal relación se robusteció gracias a los discursos televisivos: el indio es pobre y campesino, se encuentra en lo más bajo de la escala económica, pero podrá salir, como Cenicienta, si logra tener la suerte y, paradógicamente, como lo muestra el casting de las producciones, no ser indio.

\section{Una propuesta dialógica y de la semiótica de la cultura}

Como se ha visto, el fenómeno que tratamos en este ensayo es complejo e interesante, mismo que considero no se ha realizado a detalle. Por tanto, ocuparé este apartado para elaborar una propuesta de análisis de la imagen de lo indígena en el cine y la televisión mexicanos desde una perspectiva dialógica y de la semiótica de la cultura.

Para el estudio de la imagen de lo indígena en las producciones cinematográficas y televisivas mexicanas, en una clave occidental con el objeto de determinar la elaboración de discursos nacionalistas mediante la construcción de estereotipos indígenas, considero que hay que trabajar en tres vertientes que, fuera de contraponerse, se complementan: el modelo dialógico del discurso propuesto por Mijaíl Bajtín (2015); los conceptos de texto y símbolo en la Semiótica de la Cultura de Yuri Lotman (1996, 1998), y su aplicación en el estudio del cine en una vertiente semiótica (1979), que se imbrica de manera interesante con el modelo dialógico bajtiniano.

En el primer caso, con énfasis en lo concerniente a la relación establecida entre autor/héroe y con el concepto de exotopía, con lo que comprendemos la elaboración de las diferentes propuestas cinematográficas y televisivas a analizar, en función de la toma de postura del autor misma que viene determinada por su construcción axiológica. Esto quiere decir que el autor habrá de construir al héroe y a su contexto, a partir de su propia construcción histórico-social, cosa que sucede de manera constante en estos productos. Por el contrario, lo que propone Bajtín es la construcción del otro en función de un acto ético, esto es, el accionar no sólo en función de mi propia existencia, sino en el entendimiento del otro. Tatiana Bubnova, en el prólogo a "Yo también soy" de Bajtín (2015) dice que "El dialogismo resulta ser, así, un punto de vista capaz de ofrecer la posibilidad de ver y comprender todos los demás puntos de vista existentes como un evento unitario: no una abstracción del 'ser', sino un mero acontecer, su devenir conjunto con el otro" (Bubnova en Bajtín, 2015: 17). "La metalingüística de Bajtín plantea un estudio del lenguaje en el seno de la vida social" (Alejos, 2018: 21), esto es, que el lenguaje es una experiencia social y se desarrolla en términos intersubjetivos. Se plantea una relación discursiva entre sujetos o grupos de sujetos; entre culturas y sociedades. Para ponerlo en términos de José Alejos, se trata de la comunicación entre "logos".

Para Bajtín, el enunciado es una parte fundamental del estudio del lenguaje en esta postura dialógica y un "enunciado siempre crea algo que nunca había existido, algo absolutamente nuevo e irrepetible, algo que tiene que ver con los valores... pero lo creado siempre se crea de lo dado" (Bajtin, 1982: 312). Esto se refiere a lo dado por la construcción histórica del sujeto, y por el diálogo con el otro, que también es otro sujeto. Alejos denomina esto una "arquitectónica del mundo real" que queda comprendida en la fórmula "yo para mí, yo para el otro, el otro para mí" (2004: 136). Pienso que aquí hay que introducir el concepto de el "otro para sí" con lo que completamos el esquema. Lo que sucede en las cintas que he propuesto, es que las producciones no están contemplando a ese "otro para sí" ni el "yo para el otro" y sólo se elaboran desde la idea de "el otro para mí", de tal suerte que la historia está contada de manera especular, es decir, como si el cineasta (representante de la cultura y nación mexicanas) se viera al espejo y resultara que más o menos le gusta lo que ve, pero el detalle "feo" o el rasgo "negativo" siempre será el indio. Por tanto, inclusive cuando el héroe de la película sea el indio mismo, el autor lo describe siguiendo su propia construcción por lo que el 
héroe carecerá de un carácter real. De hecho, en este punto hay que señalar que no se perseguía en esencia proponer un personaje "real", sino la construcción de una figura que se acercara a los preceptos del indigenismo que hemos planteado en párrafos anteriores.

El autor, finalmente habrá de construir a su héroe desde fuera, desde una "exotopía" pues no puede ser el otro, no puede experimentar su vida misma; empero, puede intentar vivenciarla, lo que hace que su trabajo sea mucho más comprometido.

Debo experimentar intrínsecamente la vida de este otro hombre, ver axiológicamente su mundo desde el interior, del mismo modo como él mismo lo ve, ponerme en su lugar y luego, volviendo al mío propio, completar su horizonte con el excedente de la visión que se me abre desde mi lugar propio, pero ya fuera del otro... (Bajtín, 2015, pp. 28- 29).

El excedente de visión es sumamente provechoso cuando se trata de describir al otro, pues, en esencia, ese otro no puede describirse a sí mismo en toda su amplitud; no obstante, puede ser algo engañosa esa descripción si no existe una comprensión (que implica un respeto, para empezar) del sistema axiológico del otro, si no se establece esa "vivencia" de la alteridad.

Siguiendo con la propuesta teórica, considero pertinente el enlace del dialogismo con la teoría lotmaniana de la Semiótica de la Cultura, especialmente aquello relacionado con los conceptos de texto (Lotman, 1996; 1998) y símbolo (1996). Ello nos brinda mejores posibilidades de profundizar en la forja simbólica detrás de estas cintas, en contraste con realidad de las comunidades retratadas.

Para Alejos (2018), el enlace entre ambas teorías se establece por la condición dialógica que subyace en la base de la teoría lotmaniana, que se basa en la "construcción del sentido de la interacción comunicativa" (34).

La presencia de dos partenaires de la comunicación parecidos y al mismo tiempo diferentes es importantísima, pero no es la única condición para el surgimiento de un sistema dialógico... la simetría especular crea las necesarias relaciones de diversidad estructural y semejanza estructural que permiten construir relaciones dialógicas. Por una parte, los sistemas no son idénticos y emiten textos diferentes, y, por otra, se transforman fácilmente uno en otro, lo cual les garantiza a los textos una traducibilidad mutua (Lotman 1996:33, 37) (Alejos, 2018: 34)

Por tanto, para el caso del texto, será importante visualizar su función como un todo simbólico. También aquella que lo divide en dos vertientes: 1) narración verbal, que se construye como "adición de nuevas palabras, frases, capítulos" (1998: 11) y como "textomensaje internamente no discreto de tipo icónico" donde la narración es transformación, transposición interna de elementos (1998: 11).

A la luz de lo dicho, el texto se presenta ante nosotros no como la realización de un mensaje en un solo lenguaje cualquiera, sino como un complejo dispositivo que guarda variados códigos, capaz de transformar los mensajes recibidos y de generar nuevos mensajes, un generador informacional que posee rasgos de una persona con un intelecto altamente desarrollado. En relación con esto cambia la idea que se tenía sobre la relación entre el consumidor y el texto. En vez de la fórmula «el consumidor descifra el texto», es posible una más exacta: «el consumidor trata con el texto» (Lotman, 1996: 56).

Por otro lado, se ha de contemplar la idea de símbolo, que acompaña a la de texto y que, en ocasiones, se convierte en un texto en sí mismo. Esto es que "el símbolo, tanto en el plano de la expresión como en el del contenido, siempre es cierto texto, es decir, posee cierto significado único cerrado en sí mismo y una frontera nítidamente manifiesta que permite separarlo claramente del contexto semiótico circundante. Esta última circunstancia nos parece particularmente esencial para la capacidad a «ser un símbolo»" (Lotman, 1996: 102). No obstante, el símbolo fuera del contexto donde tiene lógica, que es el espacio que Lotman denomina la Semiosfera (1996), pudiera no generar ningún tipo de semiosis, es decir, que carecería de significado. Tal independencia/ dependencia del símbolo de su contexto $y$, en relación con otros espacios (semiosferas) a través de las fronteras existentes fuera de la estructura, es lo que genera el sentido sistémico de la semiótica de la cultura. En el caso que nos ocupa, las películas y programas de televisión que tratamos, desarrollan textos y símbolos que en la semiosfera occidental de los que los producen y de la generalidad de los espectadores tienen sentido, pero cuando los contrastamos con la semiosfera indígena de las comunidades que dicen representar, encontramos problemas serios de significación. Por ello, resulta pertinente la siguiente cita de Lotman

No obstante, debemos insistir en que el cine, mientras lucha por destruir el parecido con la vida natural, por destruir la fe ciega del espectador que confunde las emociones despertadas por el film con los padecimientos que originan los hechos reales (incluido el afán vulgar de solazarse con las tragedias verídicas), el cine procura conservar la fe ingenua, a veces demasiado ingenua, del espectador en que lo que ve es auténtico. El espectador poco avezado, que no sabe distinguir entre el film de ficción y el documental, de ninguna manera es el ideal, aunque es más «espectador de cine» que el crítico que estudia los métodos y que no se olvida por un solo momento de la «cocina» cinematográfica (1979: 24). 
En esa lucha por escapar de la vida "natural", los cineastas que contemplamos producen sus propios escenarios naturales y logran que ese espectador poco "avezado" (que a veces ha incluído a los propios críticos de cine en diferentes épocas) piense que lo que ve en la pantalla es un retrato de la realidad misma, indiscutible. Ello trae como consecuencia, que se puedan reforzar símbolos y textos que se encuentran por encima de la realidad, específicamente en la mente de los espectadores (como el hecho de que los actores no sean indígenas y representen una caricatura de lo indígena. Ver las figuras 1 y 2). Lo anterior, que pareciera ingenuo, por supuesto que no lo es, cuando nos percatamos que puede justificar actitudes y acciones que bien pueden ser catalogadas de racismo.

Para finalizar, considero que sería necesario contrastar las películas con personas provenientes de comunidades indígenas diversas para poder comprender cuál es la realidad que ellos perciben y si está o no de acuerdo con su propia esfera simbólica. Comparto dos investigaciones que se realizaron en este sentido, y que presentan resultados interesantes. El primero, es el estudio que desarrolló Natividad Gutiérrez Chong (2001) para mostrar cómo percibian un grupo de intelectuales indígenas los símbolos nacionales. Por supuesto, los intelectuales entrevistados no se sentían identificados con varios de ellos, especialmente con el Escudo Nacional y el "Mito Fundacional" que representa, pues no estaba integrado en las narrativas existentes en su propio devenir histórico (como los diferentes pueblos mayas).

Por otro lado, está el estudio de Doncel y Miranda (2017) en donde se mostró a varios indígenas, hombres y mujeres, que habían migrado a Monterrey, Nuevo León, desde comunidades de Veracruz, Oaxaca, Puebla o el Estado de México, el avance de la telenovela "Un refugio para el amor" (2012), donde Zuria Vega interpreta a una indígena. Por supuesto, ninguno de los integrantes de los grupos de discusión de la investigación se sintió identificado con él. Como ejemplo de lo anterior, comparto algunas de las opiniones vertidas en el grupo focal femenino sobre la vestimenta de Zuria en el avance de la telenovela:

M-I: Yo, o sea, el... o sea, el primer impacto, porque yo no vi esa novela, o sea, nada más con ver este pequeño corto, lo ves y... o sea, a mí para empezar... ni... ni siquiera su vestimenta se acerca a un real.

M-P:... de nosotros...

M-I: No, no, no, también de todos los demás. Porque si te fijaste la chava estaba súper escotada y ¿cuándo has visto a una mujer indígena súper escotada? M-Ch: Y luego el [pañuelo] que trae aquí [en la cabeza]...

M-I: O sea, está como que muy... como que lo quisieron representar como una vestimenta indígena pero muy modernizada, yo diría muy aventado. Como para... para los televidentes ¿no? Pero, ¿sí vieron el escote?, yo creo que todas lo vieron, y yo creo que nunca he visto eso así (Doncel y Miranda, 2017: 278- 279).

\section{Consideraciones finales}

Hemos analizado hasta el momento grosso modo la forma en que se ha presentado en el cine y la televisión la imagen del indio, supeditada a los intereses del Estado nacional para la construcción de una identidad nacional, primero y, segundo, para establecer "tipos" de discurso, principalmente televisivo, que coloquen estamentos sociales y su posible movilidad a través de esquemas económicos bien establecidos y una artificial idea de desarrollo y progreso. Esto, a la larga produce la sensación de que los sujetos han de buscar ser dueños de su propio destino para poder escapar de la marginación (representada por los indígenas) y llegar a ser personas exitosas que viven en la modernidad por la que pugnan los estados postrevolucionarios primero y los neoliberales después.

La propuesta teórica para la realización de este estudio es la integración del dialogismo bajtiniano con la semiótica de la cultura de Lotman que, como hemos visto, puede producir resultados interesantes. De igual manera, se puntualiza la necesidad de contrastar el análisis realizado con trabajo de campo en comunidades indígenas para conocer su opinión sobre la representación de lo indígena en la pantalla a lo largo de la historia del cine y la televisión nacionales.

Finalmente, se propone la realización de un catálogo de estos productos audiovisuales y el análisis individualizado de cada uno de ellos en los términos aquí propuestos. Este trabajo contribuirá al entendimiento de la forma en que se fue estructurando tanto la identidad nacional mexicana a través de estos medios lo que a la larga ha generado relaciones verticales entre la sociedad mexicana-mestiza-ladina, con las comunidades originarias de nuestro territorio.

\section{Referencias}

Aguirre Beltrán, Gonzalo (1957). El proceso de aculturación (1era. ed). México: UNAM

Alberro, Solange (1999). El Águila y la Cruz, orígenes religiosos de la conciencia criolla. México siglos XVI y XVII (1era. ed.). México: COLMEX, FCE.

Alejos García, José (2018). Dialogismo y Semiótica de Cuentos Míticos Mayas. México, UNAM.

Alejos García, José (2006). Identidad y Alteridad en Bajtin. Acta Poética. Número 27-1. México, UNAM.

Alejos García José (2004). "Hablar del otro en mitología maya”. En Beristáin, Helena y Ramírez Vidal, Gerardo. La palabra florida. La tradición retórica indígena y novohispana. México, UNAM.

Bajtín, Mijaíl M (2015). Yo también soy, (Fragmentos sobre el otro) (1era.ed). Buenos Aires: Godot. 
Bajtín, Mijaíl M (1982). Estética de la creación verbal. México, S.XXI.

Bonfil Batalla, Guillermo (1972). "El concepto de indio en América: una categoría de la situación colonial". Anales de Antropología. Volúmen 9 (1972). Pp. 105- 124 . Recuperado de http://www.revistas.unam.mx/index.php/antropologia/article/view/2 3077

Brading, David (2004a). Los orígenes del nacionalismo mexicano (1era ed). México: ERA

Brading, David (2004b). Mito y profecía en la historia de México (1era ed). México: CFE.

Castro-Ricalde, Maricruz (2017). "El cine mexicano de la Edad de Oro y su impacto internacional”. La Colmena 82. Abril- junio 2017, pp. 9 16. Recuperado de https://lacolmena.uaemex.mx/article/view/5371. Fecha de acceso: 23 mayo 2020

Castro-Ricalde, Maricruz (2011). "La India María en el cine mexicano». Cinémas d'Amérique latin [En ligne], 19.

URL: $\quad$ http://journals.openedition.org/cinelatino/991; $\quad$ DOI: https://doi.org/10.4000/cinelatino.991

Doncel de la Colina, Juan Antonio y Miranda Villanueva, Óscar Mario (2017). "Percepción y consumo de telenovelas e identidad étnica de universitarios y universitarias indígenas: el caso de Un refugio para el amor'. Comunicación y Sociedad, Núm. 30, septiembre-diciembre, pp. 265-285.

De la Peña Martínez, Francisco (2014). Por un análisis antropológico del cine. Imaginarios fílmicos, cultura y subjetividad (1era. ed.). México, ediciones Navarra.

Dussel, Enrique (1994). 1492. El encubrimiento del otro. Hacia el origen del "mito de la Modernidad”. Bolivia, UMSA.

Florescano, Enrique (2005). Imágenes de la patria a través de los s iglos (1era. ed.). México: Taurus.

Florescano, Enrique (2003). Etnia, Estado y Nación (1era. ed., 2da. reimpresión). México: Taurus.

Gutiérrez Chong, Natividad (2015) El indigenismo del PAN y el festejo del bicentenario del Estado Mexicano (1era, ed.). México: UNAM Instituto de Investigaciones Sociales/Bonilla Artigas Editores. Recuperado

de

http://ru.iis.sociales.unam.mx/jspui/bitstream/IIS/5209/1/indigenism o\%20PAN.pdf

Gutiérrez Chong, Natividad (2001). Mitos Nacionalistas e Identidades Étnicas; los Intelectuales Indígenas ante el Estado Mexicano (1era. ed.). México: CONACULTA.

Gruzinski, Serge (1990/2006). La guerra de las imágenes. De Cristóbal Colón a "Blade Runner" (1492-2019). México: FCE.

Hale, Charles A. (2002). La transformación del liberalismo en México a fines del siglo XIX. México: FCE.

Lafaye, Jacques (2002). Quetzalcóatl y Guadalupe, la formación de la conciencia nacional (1era. ed.). México: FCE.

Lepe-Carrión, Patricio (2012). "Civilización y barbarie. La instauración de la 'diferencia colonial' durante los debates del siglo XVI y su encubrimiento como 'diferencia cultural'". Andamios, Volumen 9, número 20, septiembre-diciembre, 2012, pp. 63-88 DOI: http://dx.doi.org/10.29092/uacm.v9i20.371

León O'Farrill, Israel (2020). Rey Kanek. Historia y mito en la construcción de la identidad maya itza'. México, Ediciones del Lirio.

Lotman, Yuri (1996). La semiosfera I. Semiótica de la cultura y del texto. España: Cátedra.

Lotman, Yuri (1998). La semiosfera III. Semiótica de las artes y de la cultura. España: Cátedra.

Lotman, Yuri (1979) Estética y semiótica del cine. España: Gilli.

Navarrete, Federico (2018). Hacia otra historia de América. Nuevas miradas sobre el cambio cultural y las relaciones interétnicas. México: UNAM. Recuperado de http://www.historicas.unam.mx/publicaciones/publicadigital/libros/o trahistoria/america.html

Navarrete, Federico (2016). México racista. Una denuncia. México: Grijalbo.
Pérez García Martha Estela y Sandra Adriana Leal Larrarte (2017). "Las telenovelas como generadoras de estereotipos de género: el caso de México". Anagramas Rumbos y Sentidos de la Comunicación Vol. 16, No 31 pp. 167-185 ISSN 1692-2522 Julio-Diciembre de 2017. 276 p. Medellín, Colombia. DOI: 10.22395/angr.v16n31a7

Quijano, Anibal (2014). "Colonialidad del poder, eurocentrismo y América Latina". En Cuestiones y horizontes: de la dependencia histórico-estructural a la colonialidad/descolonialidad del poder. Buenos Aires: CLACSO.

Silva Escobar, Juan Pablo (2011). "La Época de Oro del cine mexicano: la colonización de un imaginario social”. Culturales. 7(13), 7- 30. Recuperado http://culturales.uabc.mx/index.php/Culturales/article/view/357

Stern, Alexandra (2000). "Mestizofilia, biotipología y eugenesia en el México posrevolucionario: hacia una historia de la ciencia y el estado, 1920-1960”. Relaciones, XXI, 081.

Tuñón, Julia (2010). “Tu mirada me descubre: el ‘otro' y la reafirmación nacionalista en el cine mexicano. En torno al premio a María Candelaria (Fernández, 1943), en Cannes”. Historias 74. pp. 81- 98. Recuperado https://www.estudioshistoricos.inah.gob.mx/revistaHistorias/wpcontent/uploads/historias 74 81-98.pdf

Vázquez León, Luis (2010). Multitud y distopía. Ensayos sobre la condición étnica en Michoacán. México, UNAM.

Vidal Bonifaz, María del Rosario (2011). "Racionalidad burocrática y dominación carismática: el cine mexicano como estrategia del Estado Nacional en México". Revista del Centro de Investigación. Universidad la Salle. (Méx.) Vol. 9 Núm. 35. Recuperado de http://revistasinvestigacion.lasalle.mx/index.php/recein/article/view/ $\underline{147}$

Villoro, Luis (1996). Los grandes momentos del indigenismo en México. México, COLMEX- FCE

\section{Figuras:}

Figura 1. Pedro Armendáriz y María Elena Marqués en escena de la película "La Perla" (1945). Archivo Casasola. Vida social. Personajes. Fotografía. D.R. Instituto Nacional de Antropología e Historia, México. Derechos reservados por los respectivos autores spa Creative Commons Attribution Non-Commercial No Derivatives (CC BY-NC-ND)

Figura 2. Pedro Infante y María Félix con directores en la filmación de la película "Tizoc" (1956). Archivo Casasola. Vida social. Personajes. Fotografía. D.R. Instituto Nacional de Antropología e Historia, México. Derechos reservados por los respectivos autores spa Creative Commons Attribution Non-Commercial No Derivatives (CC BY-NC-ND) 